\title{
Abteilung II
}

Thomas Arentzen, The Virgin in song: Mary and the poetry of Romanos the Melodist. Divinations: rereading late ancient religion. Philadelphia, University of Pennsylvania Press 2017. XIII, 265 p., 10 ill. ISBN 978-0-8122-4907-1.

This book (revised from the author's 2014 Lund University doctoral thesis) is primarily a literary study of how the Virgin Mary is depicted in the kontakia of Romanos the Melodist that are seen predominantly as poetic, authorial texts. The literary analysis of Romanos' hymns, while being at the core of ARENTZEN's discussion, is used also for broader inferences about how Mary would be perceived and venerated in sixth-century Constantinople. In practical terms, the primary scope of the book is the section of Romanos' oeuvre that, following ARENTZEN's selection, is concerned with Mary (38 hymns addressed overall, with significantly fewer closely engaged); secondly, it is the hymnographer's literary background, liturgical context, and the devotional response from contemporary audiences.

The book consists of a note on editions and translations, a list of abbreviations, four chapters, conclusion, appendix I (the Greek text of Romanos' On the Annunciation according to its sole manuscript, with ARENTZEN's translation) and appendix II (a selective concordance of Romanos' works referred to in the book that brings together significations and numbering used in P. MAAS' and C. A. TRYPANIS' Oxford edition, J. GROSDIDIER DE MATONS' Paris edition, editorial titles of the hymns and their Greek incipits according to the Oxford edition), notes and bibliography, a collective index (8 pages only), and acknowledgements. The book has ten black-and-white illustrations (images of manuscripts of Romanos' kontakia, broadly relevant late antique and Byzantine art).

In Chapter 1 "The song and the city", ARENTZEN sets ground for his analysis of Romanos' representation of Mary in subsequent chapters. In an emphatically accessible idiom (avoiding specialisms as far as possible and non-Latinized Greek words altogether, as well as discussing secondary literature only marginally in the body text), he presents a summary of the current status quaestionis on Romanos' date, life, literary and liturgical setting, and the contours of the extant corpus. The high readability and engaging presentation remains one of the main features of the book throughout, which makes it broadly accessible. Already in the first chapter, ARENTZEN highlights what will become the main threads of his subsequent discussion: the role of voice in creating the liturgical performance, Mary's female and virginal qualities as linked with the singing 
voice, the liturgical role of the audiences and their response, the always-present urban context of Mary's liturgical celebration in sixth-century Constantinople.

Chapter 2 "On the verge of virginity" is centred around annunciation as both a Gospel episode and, more significantly, as a liturgical festival and the context of Romanos' On the Annunciation (other kontakia and ancient literary parallels are also evoked). Close reading of these forms the kernel of the chapter. ARENTZEN offers an intriguing (if not entirely convincing - see below) discussion of Gabriel and Mary's dialogue as a poignantly gendered encounter charged with erotic tension. He builds on literary analysis to offer wider interpretations of the meaning of virginity as both an erotically appealing and chastely adored quality in Mary that makes her a unique female object of mental gaze and devotion in late antique Constantinople as well as a unique subject of liturgical drama unravelling in front of Romanos' urban audiences.

Chapter 3 "The Mother and nurse of our life", similarly to the previous chapter, is predominantly concerned with one kontakion (On the Nativity I) while seeking to put it into a wider literary context of Romanos', and earlier, texts. Its main theme is how the divine nursing becomes a Mariocentric, rather than Christocentric, trope in Romanos putting the Virgin into the epicentre of sung cultic enactments, liturgical drama, and the patterns of devotion of late antique urban believers. ARENTZEN further develops his earlier argument about a less-thanspiritual and ascetically presented, but, rather, an embodied, humanized, and even subtly eroticized, Mary in Romanos. He particularly stresses the hymnographer's skilful focus on the paradoxical unity of virginity and nursing, Mary's motherhood and chastity, her subordinate position towards Christ and her protective, almost salvific, stance towards the divine child and, implicitly, the entire humanity.

Chapter 4 "A voice of rebirth" offers a thought-provoking analysis of how Romanos represents the Virgin's voice as the ultimate vehicle of her salvific agency and protection of all people, from Adam and Eve (the chapter is based mostly on their portrayal and dialogues in Romanos' On the Nativity II) to late antique urban Christians in Constantinople. The discussion promotes further ARENTZEN's argument for the rise in Mary's centrality (in comparison with the relatively "voiceless" Christ) in the dispensation of salvation as depicted by Romanos and, presumably, imagined by his audiences. Through the already familiar close reading of Romanos' text, seen in the context of Hellenic and late antique literary output, ARENTZEN argues that Mary acquires her role as mediator between the humanity and Christ. This is achieved through Romanos' portrayal of her liturgically resounding, and salvation-bringing, voice that audiences would hear in the physical singularity of church services at which kontakia would be sung, and would project it onto the divine realm of their salvation. 
The conclusion "Virginity recast" weaves together the key threads of ARENTZEN's argument: Mary's paradoxical maternal, and erotically charged, virginity; her portrayal as an emphatically civic, urban, humanly relatable yet idealized maiden; her mediator's role achieved through newly re-cast frames of female agency and voice as well as re-negotiated protective, motherly and virginal, roles in relation to Christ and Christians.

This is a study that is bold, almost calculatedly provoking at times. It is no doubt engaging and illuminating. The book is exceptionally good at offering fresh perspectives at seemingly well-studied material that is often overlooked as decorative rhetorising by a late antique writer, or read en masse rather than closely and imaginatively. ARENTZEN's monograph does great work of unpacking devotional implications of literary analysis of Romanos' kontakia. It presents a holistic and compelling interpretation of how Romanos re-created a literary and liturgical Virgin Mary, through his presumably widely popular kontakia, as an urban (much in the original sense of the Roman urbanitas) youthful virgin, erotically attractive through, rather than despite, her chastity, and emphatically not a distant and ascetically-cast Theotokos. ARENTZEN's style is brisk and precise, with numerous elegant phrases that put in a nutshell the author's interesting analysis.

The questions that the book asks, and the answers it offers, are significant and relevant to broader research into late antique religion and literature. ARENTZEN's engagement with the complex dynamics of female eroticism and chastity taps well into the recent scholarship on the subject. ${ }^{1}$ Earlier studies, however, have mostly engaged with the figures of female martyrs (as narrated predominantly by male authors of literary accounts of their martyrdoms and miracles). ARENTZEN takes this line of arguing one step further and approaches the literary, liturgical, and devotional ideas about the Virgin Mary as bound up in re-negotiating female agency, virginity and eroticism, gaze, and popular devotion through literary writings.

The theoretical background of the book is also worth noticing. Quite apart from its non-exclusivist tenor and implied wider-than-specialist readership, ARENTZEN does announce, although far from emphatically, his theoretical sympathies. Through the scattered but consistent referencing of post-structuralist and post-modernist theorists such as J. KRISTEVA (p. 171), M. FouCAUlT (p. 166), or S. Goldhill (p. 59), the book's identifiable methodological lineage is made

1 E. g. V. BuRRus, Word and flesh: the bodies and sexuality of ascetic women in Christian antiquity. Journal of Feminist Studies in Religion 10 (1994), 27 -51; D. FRANKFURTER, Martyrology and the prurient gaze. JECS 17 (2009), 215-245. 
present. The theoretical underpinnings of the monograph therefore fit ARENTZEN's ultimately literary approach. They do not, however, seem to give him limitations by imposing formalized restrictions on takes and angles, but much rather inform his critical discussion fruitfully. What this theory-conscious (but not at all theory-driven) book left me asking for is a larger engagement with more recent theoretical frameworks that would be perfectly at home within ARENTZEN's project, as they ask similar questions about how religion actually works on the ground, including through texts - the "lived religion" approach now introduced through a series of publications by the Erfurt-based research group of Jörg RüPKE.

Despite its central and undeniable strengths, the book is somewhat less strong on the side of precision and rigour than it is on the side of insight and revealing analysis. Below I will discuss what I see as methodological and factual imperfections.

First, there is imprecision in historical details, assumptions framed as facts, and not entirely valid generalizations that sometimes verge on anachronisms. In a significant number of cases, this arises from reliance on isolated generalizing treatments rather than on engagement with more specialized research. To give a few examples, generalizations about late antique/early Byzantine habits and mores often rely on works that in fact discuss chronologically later developments. For example, the discussion of Byzantine war generals as typically securing royal marriages on p. 57 (which underpins an important point about the presumably eroticized episode of Gabriel and Mary's exchange) is made with reference to L. GARLAND's monograph, where instances of middle and late Byzantine empresses are the only ones discussed. ${ }^{2}$ Seeking to ground the same argument in material evidence, ARENTZEN also turns to pearls (such as Gabriel gives to Mary) as a betrothal gift in late antiquity. While this in itself may not be incorrect, the reference to C. KunsT's article (p. 73 note 124) is not exactly helpful, as the latter's chronological scope is early imperial at the latest. ${ }^{3}$ More revelantly to the scope of the book, Romanos' On the Annunciation is not necessarily the earliest hymn on this topic, as stated on p. 57. Rather, it joins a wider pool of sixth-century hymns on this theme known from papyrological evidence: P. Oxy. LXXV 5023 and, possibly (dating is debated) P.Duke. inv. 766 V, or P.Köln X 407.

2 L. GARLAND, Byzantine empresses: woman and power in Byzantium 527-1204. London/New York 1999, 4.

3 C. Kunst, Ornamenta uxoria. Badges of rank or jewellery of Roman wives? Medieval History Journal 8 (2005), 127 - 142. 
Questionable chronological compatibility is, unfortunately, also pervasive in how ARENTZEN's introduces literary comparanda for Romanos' tropes and imagery - a strand of discussion which is central to his argument. Imperial, Hellenistic as well as earlier authors are forced into dialogue with Romanos' hymns. Sappho (p. 58), Aristophanes (p. 70), Sophron of Syracuse (p. 73), Aristotle (p. 66), Aulus Gellius and Plutarch (pp. 89-90) are introduced as literary background for Romanos' representations of females, nursing, virginity, and eroticism. Longus (pp. 59-60) and Achilles Tatius (p. 49) as authors of the Greek novel loom particularly large within the book's argument as instances of literary engagement with chaste yet sexually compelling maidens (p. 70 f). These literary encounters and contexts, never problematized or justified, are arguably misconstrued. It is unlikely that Romanos would be sufficiently aware of the literary texts cited, which is also true of the absolute majority of his listeners and readers in sixth-century Constantinople. Closer attention to Christian (or at least late antique) literary comparanda may have been more fruitful, including acknowledgment of Ephrem's role as the pool on which Romanos constantly drew - see e.g. Joseph's unlacing of his sandals as drawing on Ephrem, rather than Romanos' own erotically charged point (p. 70), as W.L. PETERSEN showed. ${ }^{4}$

Another problematic aspect of the presentation of argument are not always reliable translations from Greek that at some points leads to misrepresentation of Romanos' thought. To give some examples, oủ $\delta \varepsilon v$ is surprisingly rendered as "nothing [or: nobody]" on p. 64, where this presumed meaning is speculatively developed in the discussion of eroticism of Gabriel and Mary's encounter. In reference to the same episode, a number of Greek words are pressed for erotic implications through reference to later usage or to isolated, and misinterpreted,

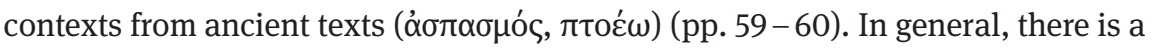
tendency to overinterpret potentially erotic idiom on the basis of chronologically detached usages (classical Greek or later Byzantine usage).

Another reservation about the book's methodology this reviewer has is the issue of translation of significantly later liturgical contexts of Romanos' kontakia (based on $10^{\text {th }}$-century liturgical manuscripts and their ascriptions of hymns to specific festal days) back into presumed sixth-century enactments. This is something that ARENTZEN does systematically. Although this procedure in itself is not impossible, it would require rigorous scrutiny of involved liturgical and manuscript data. The problem, however, is not even raised (let alone solved) in the book. One of the potentially biggest strengths of AREnTzEN's analysis - ap-

4 W.L. Petersen, The Diatessaron and Ephrem Syrus as sources of Romanos the Melodist. Louvain 1985 . 
proaching Romanos' kontakia in their performative context and discussing liturgical implications of specific points made in the hymns - is therefore jeopardized.

It may be worthwhile to take a step back and consider how this innovative and important book maps onto broader discussions of Romanos the Melodist as the early Byzantine poet (princeps melodorum). This vision, that to a significant degree is also based on his post mortem acclaim in subsequent Byzantine culture and manuscript tradition, has been widely accepted in studies at least since the early $20^{\text {th }}$ century. Today it is essentially taken for granted, and enters recent research as an unproblematic assumption. What we, however, increasingly know about the actual breadth and diversity of the corpus of early Christian hymnody and poetry in Greek, thanks to advances being made in papyrological studies, ${ }^{5}$ as well as the growing acknowledgement of Romanos' Syriac background, may require us to critically reconsider the received centrality and uniqueness of the hymnographer. After all, Romanos as the early Byzantine poet and therefore the source on popular devotion to the Theotokos in Justinianic Constantinople and wider empire may not be such a self-evident assumption to work through. This remark is offered not as criticism of ARENTZEN's study, as it would equally apply to other recent books that presume Romanos' unquestioned centrality. Rather, I offer it in the hope to raise awareness of broader implications of the study of Romanos and his literary context through which a growing body of studies operate recently, and of the research possibilities provided by the ongoing discovery, publication, and analysis of papyrological record.

To conclude: While not all ARENTZEN's specific statements and conclusions may be unassailably grounded, this is a well-written, engaging, and innovative discussion of Romanos the Melodist's Virgin Mary as seen by a literary scholar rather than a historian of the Marian cult, late antique religion at large, or an expert in sixth-century Byzantine history. It treads new paths and reconsiders important orthodoxies about Romanos and late antique veneration of the Theotokos. What this study may lack in precision it clearly makes up for in insight,

5 See e.g. C. Grassien, Problèmes d'édition dans le corpus papyrologique des hymnes chrétiennes. Archiv für Papyrusforschung 51 (2009), 253-279; Á.T. MıнÁLYKó, The Christian liturgical papyri: an introduction. Tübingen 2019. 
and is strongly recommended for anyone interested in early Byzantine hymnography, Romanos' kontakia, and the early stages of the cult of the Virgin.

Dr Arkadiy Avdokhin: National Research University Higher School of Economics, Centre for Medieval Studies, Room A 221-223, 21/4 Staraya Basmannaya Str., 105006 Russı; aavdohin@hse.ru

Michele BACCl, The mystic cave. A history of the Nativity Church in Bethlehem. Brno, Masaryk University / Rom, Viella 2017. Convivia, 1. 272 S. + Bibliographie, Indices, 81 farbige Abb. 5 Pläne. ISBN 978-88-6728-819-9.

Die Geburtskirche in Bethlehem gehört zu den am besten erhaltenen Bauten aus frühchristlicher Zeit im nahen Osten. Innenbau und Außenbau vermitteln in einmaliger Weise einen Eindruck von der frühchristlich-palästinensischen Baukunst des 6. Jh.s. Die derzeitige Restaurierung hat die ursprüngliche Farbigkeit der Mosaiken des 12. Jh.s zutage gefördert, und in mehreren Räumen kamen während der archäologischen Untersuchungen wichtige Befunde und u.a. Fresken zum Vorschein. Hinter dem Titel „A history of the Nativity Church“ verbirgt sich nicht nur eine Ereignis-Geschichte rund um die berühmte Basilika, sondern eine Beschreibung fast aller noch erfassbarer Bau- und Ausstattungsphasen, welch letztere dank der im Gang befindlichen Restaurierung in ein völlig neues Licht treten. Die Stärke der Publikation liegt in der minutiösen Berücksichtigung der Quellen und der ausführlichen Berichterstattung über die Resultate der Restaurierung; geboten wird wesentlich mehr als was der Autor als ,a general survey of previous research“ bezeichnet (S. 12).

Da bisher „no extensive archaeological investigation of the village“ Bethlehem durchgeführt worden ist (S. 33), bleibt die Frühgeschichte der Geburtskirche und ihrer Umgebung dunkel. Mit Unklarheiten behaftet ist seit je her die frühe Baugeschichte der Kirche, weil auf den bis anhin publizierten Plänen der Ausgrabungen die Höhenquoten fehlen. HARVEY hatte zwar einige Zeichnungen der Ausgrabungsbefunde von 1934 publiziert, auf denen man sehen kann, dass z. B. der Mosaikfußboden „circa 1 m“ unter dem heutigen Gehniveau der Kirche liegt. A. M. SCHNEIDER sprach von $75 \mathrm{~cm}$ (Zeitschrift des deutschen Palästina-Vereins 64, 1941, 77). Aber was soll das schon? Da HARVEY weder mit einem Nivelliergerät noch mit einem Theodoliten arbeitete, blieben Maße, Höhenquoten und Schichtenabfolgen gänzlich im Vagen. Das hatte schon RESTLE erkannt (RBK 1, 1964 „Bethlehem“ 607-608). Auf einem Plan des Atriums, den HARVEY im Quarterly of the Department of Antiquities (3, 1934, plate VII) publizierte, lieferte er die nebulöse 